Raija Kaljunen

\title{
Steel panit koulusoittimina - etnografinen tapaustutkimus musiikinopetuksesta Karjaan suomalaisella yläasteella ja Karjaan lukiossa
}

\subsection{Tutkimuksen taustaa ja tutkimusongelmat}

Steel pan (eli suomalaisittain pannu) on idiofoneihin kuuluva perkussioinstrumentti, joka perinteisesti tehdään metallisesta, toisesta päästä avoimesta öljytynnyristä. Soittopinta hakataan koveraksi irroittamatta sitä laidoista. Soittopinta jaetaan urilla, uurteilla ja/tai rei'illä kuperiin osa-alueisiin, joista jokainen on tietylle korkeudelle viritetty sävel. Kuperia alueita lyödään soittokapuloilla, jolloin saadaan aikaan säveliä. (Kronman 1992, 165.)

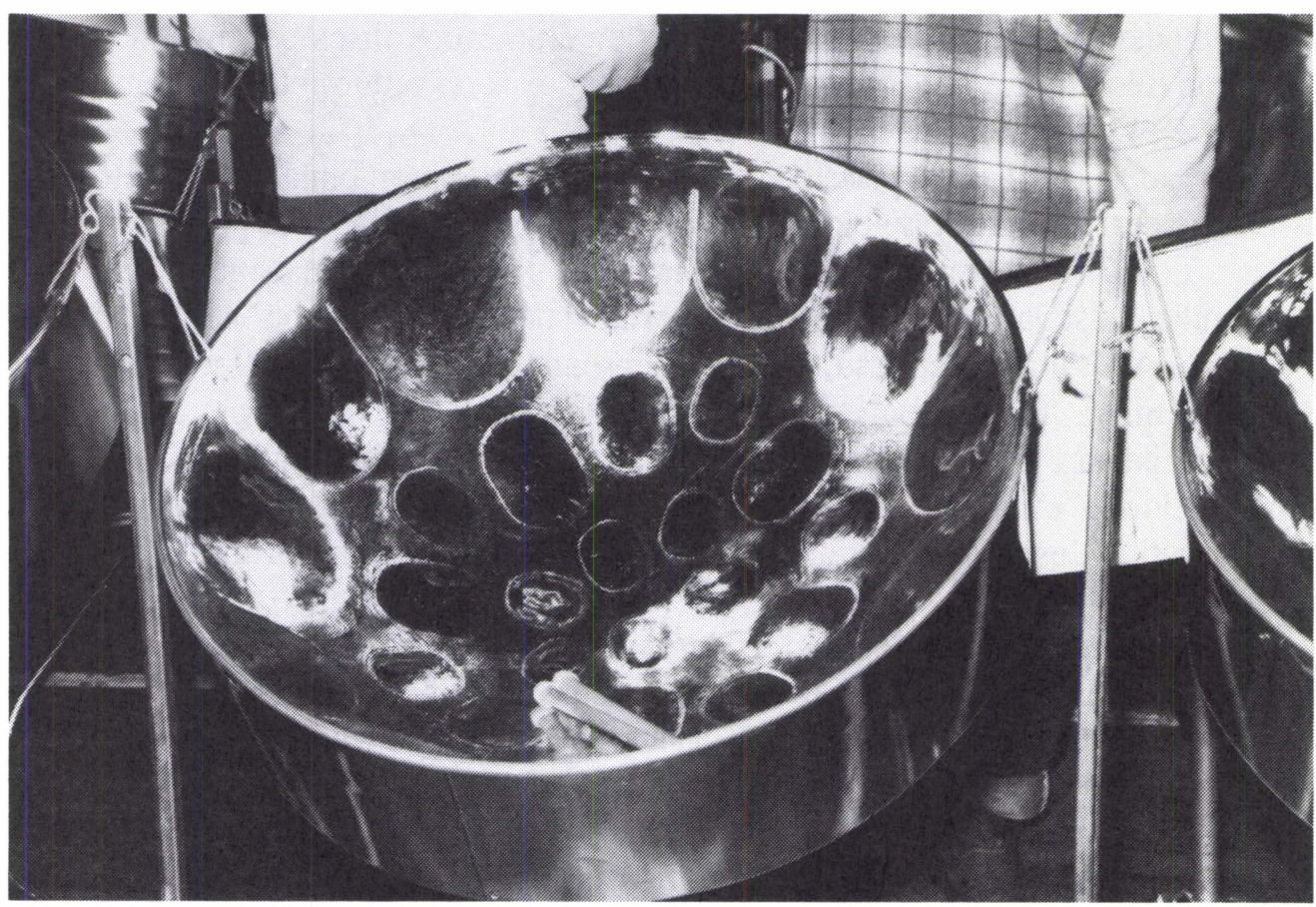

Kuva 1. Steelbandin sopraanorekisterin soitin on tenor pan. Kuva Raija Kaljunen. 
Tutustuin steel paneihin elokuussa 1991 kierrellessäni Lontoon Notting Hill Carneval -festivaaleilla, jossa steelbandien tarttuvat karibialaisrytmit herättivät mielenkiintoni ja uteliaisuuteni. Sittemmin näin kotipaikkakunnallani Lohjalla Steel Pan Lovers -yhtyeen. Syksyllä 1994 osallistuin Karjaan Steelband-yhdistyksen järjestämälle ja Ari Viitasen pitämälle yhden päivän pannukurssille, ja aiheesta innostuneena tein Karjaan steelband-toiminnasta musiikkikasvatuksen proseminaarityöni. Steel panit olivat tuolloin koulusoittimina ainoastaan Karjaan suomalaisella yläasteella ja Karjaan lukiossa, joissa Ari Viitanen työskentelee musiikinopettajana. Pro gradu -tutkielmassani olen laajentanut aihetta havainnoimalla Viitasen tunteja, tekemällä oppilaille kyselyn ja haastattelemalla heitä ja muita avainhenkilöitä.

Peruskoulun ja lukion musiikinopetus on kokenut suuria muutoksia viime vuosikymmeninä. Urkuharmonisäesteisestä yhteislaulusta on kuljettu tämän päivän toiminnallisuutta ja elämyksellisyyttä korostavaan musiikkikasvatukseen (POPS 1994, 97). Valtakunnallisista, keskusjohtoisista opetussuunnitelmista on luovuttu, ja nykyään musiikinopettajan työlle antavat puitteet enää opetussuunnitelman perusteet. Koulutuksen kehittäminen pohjautuu koulukohtaiseen opetussuunnitelma-ajatteluun, joka sisältää ajatuksen opettajasta oman työnsä kehittäjänä (POPS 1994, 9).

Lähes joka koulussa on nykyään jo perusvarusteet yhtyesoittoa varten (sähkökitara, basso ja rummut) sekä vaihteleva määrä akustisia kitaroita. "Perinteiset" koulusoittimet nokkahuilu ja Orff-soittimet (ksylofoni, metallofoni, kellopeli ym.) ovat usein jääneet taka-alalle. Musiikinopetuksen kehittämisen ajankohtainen haaste on monikulttuurisuuden eli monipuolisesti eri musiikkikulttuureihin tutustumisen nostaminen luontevaksi osaksi koulun musiikkikasvatusta (POPS 1994, 97; LOPS 1994, 101-102).

Karjaan suomalaisella yläasteella ja Karjaan lukiossa on ennakkoluulottomasti laajennettu musiikinopetuksen menetelmiä ja sisältöjä. Matka pannujen kotimaasta Trinidadista läntiselle Uudellemaalle on pitkä, eikä Länsi-Intian saariston soittimilla ensiajattelemalta luulisi olevan laajempaa käyttöä suomalaisessa koulussa. Ari Viitasen ratkaisu, säännöllinen pannujensoitto musiikintunneilla, on ainutlaatuinen, laajamittainen projekti uuden, erilaisen soittimen tuomiseksi koulumaailmaan. Steel panit ovat myös esimerkki siitä, miten yksi musiikinopettaja voi luoda oman linjansa ja toteuttaa itseään oman opetussuunnitelmansa myötä; sitkeydestä ja siitä, miten pieni idea voi kasvaa suurimittaiseksi toiminnaksi.

Yksi tärkeä näkökulma tähän aiheeseen perehtymiseen on monikulttuurisuus ja kansainvälisyyskasvatus. Steel pan on trinidadilainen soitin, jota käytetään normaalissa musiikinopetuksessa Karjaan suomalaisella yläasteella ja Karjaan lukiossa. Minua kiinnosti selvittää, miten paljon trinidadilaisuutta liittyy Ari Viitasen pannujensoitonopetukseen ja miten oppilaat suhtautuvat heille varsin vieraaseen soittimeen. Sekä peruskoulun että lukion opetussuunnitelman perusteisiin (POPS 1994, 32-33; LOPS 1994, 17) on kirjattu ympäristömme 
kansainvälistyminen ja monikulttuuristuminen ja sen myötä tarve lisätä kulttuurien tuntemusta ja kansainvälistä yhteisymmärrystä.

Kansainvälisyyskasvatuksen tavoitteena on, että oppilas hyväksyy ihmisten erilaisuuden ja tuntee erilaisia kulttuureita, ja yksi sen keskeisiä sisältöalueita on kulttuurien tuntemus ja suvaitseva suhtautuminen erilaisuuteen (POPS 1994, 33). Karjaan pannujensoitto voidaan nähdä esimerkkinä ruohonjuuritason kansainvälisyyskasvatuksesta: trinidadilainen soitin ja musiikkikulttuuri ovat muuttuneet luontevaksi osaksi suomalaista kulttuuria.

Ari Viitanen aloitti steel panien käytön koulun musiikintunneilla syksyllä 1991. Hän rakentaa ja virittää suurimman osan Karjaalla käytössä olevista pannuista sekä tekee kaikki sovitukset. Pannuilla soitetaan kaikenlaista musiikkia: iskelmiä, rock- ja pop- musiikkia sekä klassista musiikkia. Viitasen johdolla toimiva Steel Pan Lovers -yhtye koostuu edistyneimmistä soittajista ja on konsertoinut laajalti Suomessa sekä jonkin verran ulkomailla. Sen monipuoliseen ohjelmistoon kuuluu myös kalypsoa, socaa ja klassista musiikkia. Syksystä 1994 pannuja on soitettu myös Karjaan suomalaisella ala-asteella opettaja Antti Jyrkkäsen johdolla. Syksyllä 1995 Kirkkonummen yläasteelle hankittiin pannusetti ja aloitettiin pannujensoitto musiikinopettaja Satu Jämsän johdolla.

Tutkimukseni tavoite on selvittää, miten Ari Viitanen käyttää steel panejä koulusoittimina: ovatko ne todella niin helppoja ja monipuolisia koulusoittimia, kuin mitä Viitanen korosti haastatellessani häntä proseminaarityöhöni. Tavoitteenani on myös saada selville, millainen musiikkikasvatusfilosofia Ari Viitasella on eli millaisten periaatteiden mukaan hän tekee työtään. Selvitän yläasteen ja lukion oppilaiden ja muiden asiaan liittyvien suhtautumista steel paneillä soittamiseen.

Tarkoitukseni on myös verrata Karjaan pannujen käyttöä artikkelien ja haastattelun pohjalta kokemuksiin Iso-Britanniassa, Yhdysvalloissa sekä Sveitsissä, joissa steel panit ovat huomattavasti tunnetumpia kuin Suomessa. Vertailusta ei tule kovin kattavaa, sillä kirjallisuutta aiheesta on hyvin niukalti saatavissa. Tarkoitukseni on lähinnä verrata keskeisiä käytäntöjä, periaatteita ja kokemuksia. Vertailua aion tehdä myös Antti Jyrkkäsen, Satu Jämsän ja Ari Viitasen kokemuksista pannuista koulusoittimina.

Varsinaista hypoteesiä tutkimuksessani ei ole, sillä tarkoitukseni on kuvailla ilmiötä, ei testata etukäteen tehtyjä oletuksia. Pääkysymyksiä tutkimuksessani ovat, mitä ja miksi Ari Viitanen tekee musiikintunneillaan; mitä mieltä oppilaat ovat steel paneistä sekä miten muut asianosaiset suhtautuvat pannuihin. Alakysymyksinä pohdin muun muassa, miksi ja miten Viitanen käyttää steel panejä. Pyrin myös selvittämään hänen musiikkikasvatusfilosofiaansa. Oppilaiden haastatteluista haen vastausta siihen, mitkä seikat ovat helppoja ja mitkä vaikeita pannujensoitossa ja kuinka paljon pannuja on oppilaiden mielestä soitettu. Pyrin saamaan selville, mitä pannujensoitto on merkinnyt heille. Muita alakysymyksiä on koulun suhtautuminen Viitasen laajamittaiseen, tavanomaisesta poikkeavaan musiikinopetukseen. Tätä varten haastattelin sekä yläasteen että lukion rehtoria. 
Selvitin myös Antti Jyrkkäsen ja Satu Jämsän kokemuksia pannuista koulusoittimina.

Tutkimukseni rajoittuu Ari Viitasen musiikinopetuksen osalta lähinnä pannujensoiton tutkimiseen, ei niinkään hänen muuhun musiikinopetukseensa. Aika, välimatkat ja opettajaharjoittelun suorittaminen rajoittivat kenttätyöjaksojen määrää keväällä 1996, joten mitään säännöllistä oleskelua Karjaalla en valitettavasti voinut toteuttaa. Kyselylomaketta en jakanut kaikille Viitasen oppilaille (yhteensä noin 400), vaan otokseni oli 114 oppilasta eri luokka-asteilta. Haastateltavien määrää oli myös rajattava. Tutkimukseni painottuu Karjaan suomalaisen yläasteen musiikinopetukseen, sillä Karjaan lukiossa pannuja soitetaan lähinnä steelband-kurssilla, ei juurikaan pakollisilla musiikin kursseilla. Tutkimukseni ei myöskään keskity lyhyttä kuvausta tarkemmin Steel Pan Loversiin tai Karjaan Steelband-yhdistykseen.

\subsection{Tutkimuksen metodit}

Jo proseminaarityössäni päädyin laadulliseen tutkimukseen, sillä mielestäni tällaista uutta ilmiötä ei voi tutkia koeasetelmin tai postikyselyin. Tätä tutkimusta suunnitellessani pysyin samoilla linjoilla perehtyen tapaustutkimukseen ja etnografiaan. Laadullisessa tutkimuksessa tutkija on kiinnostunut prosessista, ymmärtämisestä ja merkityksistä, ei niinkään lopputuloksesta. Tutkija on itse tiedonkeruun ja analysoinnin pääväline. Laadullinen tutkimus on kuvailevaa, induktiivista ja edellyttää yleensä kenttätyötä. Induktiivisuus merkitsee sitä, että tutkija pikemminkin luo käsitteitä ja hypoteeseja kuin testaa olemassaolevaa teoriaa. (Merriam 1988, 19-20.)

Menetelmien valinnassa havainnointi, haastattelut, valokuvaus ja videointi olivat varsin luontevia, koska sivuaineeni yliopistossa on journalistiikka ja olen myös työskennellyt toimittajana. Kyselyn liitin mukaan, koska halusin saada yleiskuvan oppilaiden suhtautumisesta pannuihin.

\subsubsection{Tapaustutkimus}

Tapaustutkimus on tutkielma tarkoin määrätystä, rajatusta ilmiöstä tai järjestelmästä kuten opetusohjelmasta, tapahtumasta, henkilöstä, prosessista, instituutiosta tai sosiaaliryhmästä (Merriam 1988, 9). Tapaustutkimuksessa käytetään useimmiten havainnointia ja haastattelua, mutta mitään metodia ei suljeta pois. Tapaustutkimuksen suuri voima on siinä, että se sallii tutkijan keskittyä tiettyyn tilanteeseen ja yrittää tunnistaa käynnissä olevat erilaiset interaktiiviset prosessit. Usein tutkija tunnistaa tapauksen, joka voi olla esimerkiksi uusien opetussuunnitelmien esittely; tapa, jolla koulu sopeutuu uuteen rooliin tai mikä tahansa keksintö tai kehityksen taso instituutiossa. Tapaustutkija havainnoi, kyselee ja 
tutkii. Hän tähtää kunkin organisaation yleisten ja ainutlaatuisten piirteiden tunnistamiseen ja näyttämään sen, miten ne vaikuttavat systeemien toteuttamiseen ja siihen, miten organisaatio toimii. (Bell 1987, 6-7.)

Tapaustutkimuksessa lähtökohta on yksilöiden kyky muodostaa merkityksiä maailmasta, jossa toimivat, ja kyky tulkita inhimillisen elämän tapahtumia. Tapaustutkimus on kokonaisvaltaista, elävää ja yksityiskohtaista kuvausta todellisuudesta. Siinä yhdistetään eri tieteiden teorioita, ja ilmiötä tutkitaan sen luonnollisessa ympäristössä ilman keinotekoisia pakotteita ja järjestelyjä. Tutkija ja tutkittavat ovat keskenään vuorovaikutuksessa. Tapaustutkimus on mukautuvaista, sillä tapauksen valinta perustuu harkintaan, onko kohteeseen pääsy ja luottamuksellisten suhteiden kehittyminen mahdollista. Tutkimus voi myös muuttua toteutuksen ja tavoitteiden suhteen todellisen tilanteen olosuhteiden perusteella. Tapaustutkimus on myös arvosidonnaista, sillä tutkijan koko persoonallisuus ja arvomaailma ovat mukana tutkimuksessa ja vaikuttavat näkemyksiin, jotka hän muodostaa tutkimuskohteesta. (Syrjälä - Numminen 1988, 8-11.)

Tapaustutkimuksessa keskitytään yhden yksikön moniin, mahdollisesti jopa kaikkiin muuttujiin. Kaikkia tärkeitä muuttujia ei ole mahdollista etukäteen määritellä. Tulokset esitetään kvalitatiivisesti sanoin ja kuvin, ei niinkään numeroin. Tapaustutkimus ei vaadi mitään tiettyä metodia tiedonkeruuseen ja -analysointiin, ja se voi sisältää myös kyselyllä kerättyä tietoa. Tutkija on kiinnostunut pikemminkin ilmiön syvästä ymmärtämisestä, uusista löydöistä ja tulkinnasta eikä niinkään hypoteesien testaamisesta. (Merriam 1988, 7-8, 10.)

Tapaustutkimuksessa on tärkeää tutkia samaa asiaa monin eri metodein ja hankkia monipuolisin tavoin aineistoa, jolloin eri menetelmin saadut tiedot validoivat ja täydentävät toisiaan. Tämä triangulaatio on tapaustutkimuksessa keskeistä, ja sen avulla on mahdollista ymmärtää ilmiön moniulotteisuutta tai kuvata osallistujien ilmiöön liittämiä erilaisia merkityksiä. Triangulaation avulla tutkija vertailee tietolähteitä testatakseen tiedon laatua, ymmärtääkseen täydellisemmin tilanteen osapuolia ja asettaakseen koko tilanteen oikeisiin mittasuhteisiin. Tutkija vertailee analyysin aikana niitä yksiköitä ja tasoja, jotka ovat vertailtavissa. (Fetterman 1989, 89-90; Syrjälä - Numminen 1988, 78-79.)

Tapaustutkimus tarjoaa keinon tutkia monimutkaisia sosiaalisia yksikköjä monine muuttujineen, joilla on potentiaalista merkitystä ilmiön ymmärtämisessä. Tapaustutkimus antaa rikkaan ja kokonaisvaltaisen kuvan ilmiöstä ja sillä on tärkeä merkitys jonkin alan tietokannan kehittämisessä. Se on osoittautunut erityisen hyödylliseksi kasvatuksellisten innovaatioiden tutkimuksessa. (Merriam 1988, 32-33.)

Vaikka rikas ja yksityiskohtainen kuvaus ilmiöstä onkin toivottavaa, tutkijalla ei ole välttämättä aikaa tai rahaa toteuttaa niin isoa projektia, ja vaikka olisikin, tulosta voidaan arvostella liian pitkäksi, liian yksityiskohtaiseksi tai liian syvälliseksi. Guban ja Lincolnin mukaan (Merriam 1988, 34) tapaustutkimus voi yksinkertaistaa liikaa tai liioitella tilannetta ja johtaa siten lukijan vääriin tulkintoihin tilanteesta. Tutkija on aineiston keruun ja analysoinnin pääväline: hän 
jää usein omien vaistojensa ja kykyjensä varaan ilman koulutusta tai opastusta. Myös reliabiliteetti, validiteetti ja yleistettävyys on nähty tapaustutkimuksen puutteina. (Merriam 1988, 33-34.)

\subsubsection{Etnografinen tapaustutkimus}

Syrjälä ja Numminen $(1988,23)$ määrittelevät etnografian eli etnografisen tutkimuksen yhdeksi tapaustutkimuksen tyypiksi. Heidän mukaansa etnografia on tapa kuvata ihmisten elämää, jolloin se perustuu pitkäaikaiseen oleskeluun yhteisössä. Etnografiassa ollaan kiinnostuneita käyttäytymisestä suhteessa ryhmään ja sen merkityksen tulkinnasta ryhmän kulttuurin kannalta. Aineistoa kerätään empiirisesti ja naturalistisesti. Tutkimuksen lähtökohtana olevat kysymykset täsmentyvät tutkimuksen edetessä, ja tutkimus on monimetodista. Etnografiassa ilmiötä kuvataan kaikissa eri yhteyksissään eli tutkimus on holistista. Etnografisessa tutkimuksessa on keskeistä riittävä ajallinen kesto. Tutkimuksen suhde teoriaan vaihtelee: voidaan pyrkiä pelkkään kuvaukseen tai tavoitella korkeaa teoreettista tasoa. (Syrjälä - Numminen 1988, 24-26; Syrjäläinen 1990, 16.)

Olennaista etnografiassa on tutkia kulttuuria, ryhmää tai yhteisöä sisältäpäin ja pyrkiä tallentamaan osallistuvan havainnoinnin avulla, miten tutkittavat yksilöt havaitsevat, konstruoivat ja ovat vuorovaikutuksessa taloudellisen ja sosiaalisen ympäristönsä kanssa (Syrjälä - Numminen 1988, 27). Etnografi etsii ajatus- ja käyttäytymiskuvioita, jotka toistuvat eri tilanteissa ja eri osallistujilla. Näiden kuvioiden etsiminen on yksi analyysimuoto. Jokaisessa sosiaalisessa ryhmässä on avaintapahtumia, joita tutkija voi käyttää analysoidakseen kokonaista kulttuuria. Usein avaintapahtuma on metafora elämäntavasta tai erityisestä sosiaalisesta arvosta. (Fetterman 1989, 92-93.)

Etnografia käsitteenä on peräisin antropologiasta, ja sitä on viime aikoina käytetty erotuksetta muun muassa kenttätyön, tapaustutkimuksen ja laadullisen tutkimuksen kanssa. Antropologeille termillä on kuitenkin kaksi erillistä merkitystä. Etnografia tarkoittaa joukkoa tiedonkeruumetodeja sekä etnografisten tekniikoiden käytön seurauksena syntynyttä kirjallista tuotetta. Etnografisten metodien käyttäminen ei sinänsä tuota etnografiaa sanan jälkimmäisessä merkityksessä, sillä etnografia on aineiston sosiokulttuurinen tulkinta. Tällöin esimerkiksi koulua koskevassa etnografisessa tapaustutkimuksessa otettaisiin mukaan myös yhteisö laajemmin ja sen kulttuurinen konteksti: alueen historia, sosioekonomiset tekijät, vanhempien mielipiteet jne. Myös Syrjälä ja Numminen huomioivat tämän eron, ja toteavat olennaiseksi seikaksi etnografiasta puhuttaessa kulturaalisen tulkinnan. Myös Lutz haluaa erottaa (Syrjäläinen 1990, 16) etnografisen tutkimuksen etnografiasta: edellinen voi keskittyä pelkästään tiheään kuvaukseen ja holistisuuteen, mutta etnografian on Lutzin mielestä havaittava ja otettava huomioon tutkimuskohdetta ympäröivät ja siihen vaikuttavat yhteiskunnalliset 
syy-yhteydet. Yleensä etnografisessa tutkimuksessa pyritään ankkuroimaan tulosten tulkinta laajempiin yhteyksiin. (Merriam 1988, 23-24; Syrjälä - Numminen 1988, 26; Syrjäläinen 1990, 16.)

Usein etnografisissa tutkimuksissa erotetaan eeminen ja eettinen näkökulma. Eeminen näkökulma, sisäpiiriläisen tai natiivin, on valtaosassa etnografista tutkimusta keskeisellä sijalla. Sisäpiiriläisen näkemys todellisuudesta vaikuttaa tilanteiden ja käyttäytymisen ymmärtämiseen ja tarkkaan kuvaukseen. Eettinen näkökulma on ulkopuolinen, sosiaalitieteellinen näkökulma todellisuuteen. Nykyään etnografit aloittavat yleensä aineiston kokoamisen eemisestä näkökulmasta, minkä jälkeen he yrittävät ymmärtää keräämäänsä sekä natiivin että oman tieteellisen analyysinsä näkökulmasta. Hyvä etnografia vaatii sekä eemistä että eettistä näkökulmaa. (Fetterman 1989, 30, 32.)

Kasvatustieteessä etnografia on tutkimustyyppi, joka lisääntyy ja kehittyy voimakkaasti (Syrjälä - Numminen 1988, 24). Amerikkalaisessa, brittiläisessä ja saksalaisessa kasvatustieteen tutkimuksessa etnografista metodologiaa on käytetty yleisesti. Suomessa kasvatustieteen tutkimuksessa ei juuri ole etnografista tutkimusotetta käytetty koululuokan tutkimuksessa. Eija Syrjäläinen on tutkimuksessaan (1990) luokkahuoneyhteisöstä ottanut mallia lähinnä amerikkalaisesta tutkimuksesta. (Syrjäläinen 1990, 15, 18.)

Syrjäläisen tutkimus on kuvausta ja analysointia peruskoulun ja steinerkoulun 4. vuosiluokan oppilaiden ja opettajan roolikäyttäytymisestä. Syrjäläisen tutkimusmenetelmiä olivat osallistuva havainnointi, haastattelu ja keskustelut. Hän kirjoitti kenttämuistiinpanoja, nauhoitti oppitunteja ja haastatteluja, valokuvasi ja keräsi kirjallisia dokumentteja. Syrjäläinen käytti sosiaalipsykologian käsitteistöä analysoidessaan roolikäyttäytymistä. Laajemmassa perspektiivissä Syrjäläinen ei pyri yleistämään analyysin tuloksia, vaan pohtii analyysistä nousseita teemoja yleisemmällä tasolla (Syrjäläinen 1990, 4).

\subsubsection{Etnografia etnomusikologiassa ja musiikkikasvatuksessa}

Etnomusikologiassa kenttätyö on alusta alkaen ollut keskeistä. Musiikin etnografia voidaan nähdä kuvailevana lähestymistapana musiikkiin, siinä ei tyydytä kirjoittamaan muistiin pelkästään ääniä, vaan selvitetään, miten äänet ilmaistaan, tehdään ja miten ne vaikuttavat toisiin yksilöihin, ryhmiin, sekä sosiaalisiin ja musiikillisiin prosesseihin. Musiikin etnografia kertoo, miten ihmiset tekevät musiikkia. Se on analyyttinen tapahtumien transkriptio, joka sisältää yksityiskohtaisia kuvauksia sekä yleisiä lausuntoja ihmisten musiikista perustuen henkilökohtaiseen kokemukseen tai kenttätyöhön. Pitkään alalla on ollut illuusio, että musiikki voi olla olemassa erillään esiintyjistä ja yleisöstä, mikä on johtanut alan kahtiajakautumiseen: on tehty tutkimuksia, joissa on tutkittu ääniä ja unohdettu täysin yleisön ja esiintyjien vuorovaikutus tai keskitytty pelkästään siihen unohtaen tuotetut äänet. (Seeger 1992, 88-89.) 
20 viime vuoden aikana etnografiat ovat lähestyneet musiikkia natiivin näkökulmasta käyttäen heidän ilmaisukategorioitaan. Eräät tutkijat ovat myös opetelleet soittamaan uusia soittimia tai musiikkityyliä, ja kuvanneet sitten etnografioissaan kohtaamisia muusikoiden kanssa ja musiikkielämää oppilaan ja esiintyjän näkökulmasta. (Seeger 1992, 101, 103.)

Alan Merriamin tutkimusmalli (1978, 32-33) jakaa musiikin kolmelle eri tasolle: käsityksiin musiikista, musiikkiin liittyvään käyttäytymiseen ja musiikilliseen ääneen. Soiva musiikillinen ääni on tulos käyttäytymisestä, joka tuottaa äänen. Käyttäytymistä on kolmea eri lajia: fyysinen, sosiaalinen ja verbaalinen käyttäytyminen. Fyysinen käyttäytyminen viittaa fyysiseen äänen tuottamiseen, kehon liikkeisiin ääntä tuotettaessa ja niin edelleen. Sosiaalinen käyttäytyminen liittyy muusikolta ja ei-muusikolta odotettuun käyttäytymiseen musiikillisessa tapahtumassa. Verbaalinen käyttäytyminen tarkoittaa sanallisia ilmauksia musiikista. Kaikkea käyttäytymistä ohjaavat käsitykset musiikista. Yksilön täytyy tuntea ero melun ja musiikin välillä, musiikin lähteet, mikä on musiikin alkuperä ja niin edelleen. (Merriam 1978, 32-33.)

Slobin ja Titon $(1992,4)$ esittävät musiikkikulttuurin mallin, joka koostuu musiikin vaikutuksesta, esityksestä, yhteisöstä ja muistista/historiasta. He esittävät myös musiikkikulttuurin neljä osatekijää (Slobin - Titon 1992, 6):

1. Käsitykset musiikista: musiikki ja uskomukset, musiikin estetiikka, musiikin konteksti ja musiikin historia

2. Musiikin sosiaalinen organisointi

3. Ohjelmistot: tyyli, genret, tekstit, säveltäminen, musiikin välittäminen eteenpäin ja liikkuminen (= fyysinen liike soitettaessa, tanssi)

4. Materiaalinen kulttuuri (= soittimet, nuotit)

Näitä molempia, sekä Merriamin että Slobinin ja Titonin malleja ja jaotteluja olen käyttänyt pohtiessani steel panien käytön eri aspekteja. Erityisesti haastatteluteemoja pohtiessani olen käynyt läpi edellä esitettyjä jaotteluja saadakseni mahdollisimman kattavan kuvan ilmiöstä. Nähdäkseni näitä molempia lähestymistapoja seuraamalla syntyy etnografia tietystä musiikkikulttuurista.

Musiikkikasvatuksen tutkimuksen ensimmäisinä vuosikymmeninä kannatettiin kvantitatiivisia malleja. 1960-luvun loppupuolella kasvatustieteessä havahduttiin kasvatuksellisen tasa-arvo- ja muun keskustelun myötä huomaamaan, että tarvittiin myös laadullisia lähestymistapoja. Musiikkikasvatus seurasi tätä tietä noin vuosikymmenen myöhemmin. Yhdysvalloissa etnomusikologian menetelmiä - havainnointia, haastattelua, arkistomateriaalin käyttöä ja syventymistä tiettyyn tapaukseen - on käytetty kasvavassa määrin musiikkikasvatuksen tutkimuksissa. On mm. tutkittu kartoittamattomia alueita, jotta voitaisiin ymmärtää musiikillista toimintaa kontekstissaan, sekä uusia keksintöjä, esimerkiksi tietokoneen käyttöä musiikintunneilla. (Bresler - Stake 1992, 79-80, 82.)

Tämä tutkimus on Syrjälän ja Nummisen $(1988,23)$ mukaan määriteltynä etnografinen tapaustutkimus. Näkökulmani on musiikkikasvatuksellinen, mutta 
mukana on myös etnomusikologista vivahdetta: vaikka musiikkikulttuuriin tutustumiseksi en viettänyt pitkää kenttätyöjaksoa enkä nuotintanut kuulemaani musiikkia, olen kuitenkin oleskellut kentällä useaan otteeseen pitkän ajan kuluessa, kuvaan soittimen rakennetta, historiaa, ohjelmistoja ja liitän tutkimukseeni yhden nuottiesimerkin. Etnografian olennaisen piirteen, aineiston sosiokulttuurisen tulkinnan suhteen tavoitteenani on kuvailla ja selittää pannutoimintaa koulukulttuurina. Vaikka joitakin aspekteja ilmiöstä (Steel Pan Lovers, Karjaan Steelband-yhdistys) jätetään tarkemmin käsittelemättä, on tavoitteenani yrittää ymmärtää ja tulkita steel pan-toimintaa yleisemmällä tasolla. Tarkoitukseni on siis edetä pelkän kuvailun asteelta pohtimaan ja analysoimaan ilmiötä ja sen merkitystä laajemminkin musiikkikasvatuksen kannalta ja siten yhdistää sekä eeminen että eettinen näkökulma. Koska etnografiaa ja etnografista tutkimusta käytetään edelleen monissa eri merkityksissä, on tämänkin tutkimuksen yksiselitteinen rajaaminen tietyn otsikon alle vaikeaa.

\section{Aineistonkeruu ja analyysi}

\subsection{Kenttätyö}

Tätä tutkimusta varten vietin kolme kenttätyöjaksoa Karjaalla: 8.-12.1., 26.2-1.3. ja 9.-12.4.1996. Näistä ensimmäisellä ja toisella jaksolla seurasin koko viikon Ari Viitasen tunteja. Huhtikuun jaksolla tein oppilaiden haastattelut ja seurasin enää vain muutaman tunnin. Olen tutkimuksen alusta saakka eli syyskuusta 1995 pitänyt tutkimuspäiväkirjaa, johon olen kirjannut ideoita, kirjallisuuslähteitä, liimannut lehtileikkeitä, merkinnyt muistiin omia tuntemuksiani eri vaiheissa sekä hoidettavia asioita. Kenttätyöjaksoilla tein muistiinpanoni kenttäpäiväkirjaan, jonka kirjoitin puhtaaksi aina kenttätyöjaksojen päätyttyä. Tutkimuspäiväkirjaani en ole kirjoittanut puhtaaksi, se on ollut täysin henkilökohtainen.

Ensimmäinen kontaktini kentälle oli luonnollisesti Ari Viitanen, jolle ajatukseni tulla seuraamaan hänen tuntejaan ei mitenkään tuntunut vastenmieliseltä. Jo alusta asti hän vaikutti innostuneelta ja kannustavalta tutkimukseni suhteen. Ensimmäiset viralliset kontaktini sekä yläasteen että lukion rehtoreihin otin joulukuussa 1995, jolloin kerroin tutkimuksestani ja pyysin lupaa saada tulla sitä suorittamaan. Luvan saannissa ei ollut ongelmia, ja toimitin molemmille rehtoreille tutkimussuunnitelmani ennen ensimmäisen kenttätyöjakson aloittamista. Ensimmäisen kenttätyöjaksoni alussa esittelin itseni yläasteen henkilökunnan työpaikkakokouksessa ja kerroin lyhyesti, miksi olen koululla. Koko kenttätyöni ajan opettajat tuntuivat suhtautuvan positiivisesti tutkimukseeni ja kyselivät sen edistymisestä aina Karjaalla käydessäni. 


\subsubsection{Havainnointi}

Tieteellinen observointi vaihtelee hyvin informaalista täysin systemaattiseen havainnointiin. Sitä voidaan käyttää rinnan muiden menetelmien kanssa. Se on systemaattista, ei satunnaista arkipäivän tarkkailua: tutkija eristää tilanteen keskeisiä piirteitä tarkkailtaviksi. (Hirsjärvi - Hurme 1988, 17.)

Ulkopuolisena havainnoija huomaa osanottajien rutiineiksi muodostuneet asiat. Osallistuva havainnoija näkee asiat paikanpäällä, saa ensikäden tietoa ja pystyy kirjaamaan käyttäytymistä niin kuin se tapahtuu. (Merriam 1988, 88.)

Havainnoijan rooli voi vaihdella täydellisen osanottajan ja täydellisen havainnoijan välillä. Usein tapaustutkija on Gansin mukaan (Merriam 1988, 93) tutkijaosanottaja (researcher participant) eli osallistuu tilanteeseen vain osittain henkilökohtaisesti sitoutuneena ja voi siten toimia myös tutkijana. (Merriam 1988, 9293.)

Havainnointimuistiinpanojen tarkkuusaste voi vaihdella. Muistiinpanot pitäisi kuitenkin puhtaaksikirjoittaa mahdollisimman pian kentälläolon jälkeen. Kenttämuistiinpanot sisältävät yleensä sanallisia kuvauksia ympäristöstä, ihmisistä ja tapahtumista; suoria lainauksia tai ainakin puhutun sisällön sekä havainnoijan kommentteja, jotka sijoitetaan joko marginaaliin tai merkitään tekstiin alleviivauksin tai nimikirjaimin varustettuna. (Merriam 1988, 96-98.)

En käyttänyt havainnoinnissani mitään strukturoitua lomaketta, vaan kirjasin omin sanoin ylös tapahtumia tuntien kuluessa. Oma roolini oli avoin; esittelin itseni joka tunnin alussa ja kerroin, kuka olin ja miksi olin seuraamassa tuntia. Istuin luokan sivussa enkä puuttunut tunnin kulkuun. Jälkikäteen ajateltuna olisi ollut ehkä hyödyllistä mennä soittamaan jonkin ryhmän kanssa ja siten kokeilla, miltä Arin opetus tuntuu oppilaista. En kuitenkaan tehnyt tällaista kokeilua, sillä kenttätyöjaksojen rajallisuuden takia tuntui tärkeämmältä yrittää aistia tunnelmaa rauhassa luokan sivusta ja saada yleiskuvaa steel paneista koulusoittimina. Toki kokeilin pannujensoittoa välituntisin.

Kenttämuistiinpanoni sisältävät pohjapiirroksia, kuvauksia ihmisistä sekä omia kommenttejani tapahtumiin. Nämä omat tulkintani erotin tekstissä nimikirjaimillani tosiasiallisista tunnin tapahtumista ja kokosin ne puhtaaksikirjoitusvaiheessa aina joka tunnin loppuun omaksi osuudekseen. Jonkin verran muistiinpanoissani lomittuvat myös omat tulkintani tapahtumien kuvauksen keskellä, sillä joskus tuntui keinotekoiselta erottaa niitä tapahtumavirrasta. Omista kommenteistani kohosi jälkeenpäin paljon teemoja analysoinnin pohjaksi, ja varsin usein jo ensimmäiset, intuition pohjalta muistiinmerkityt seikat osoittautuivat olennaisiksi piirteiksi ilmiössä.

Havainnoinnin kesto määräytyi melko lailla käytännön sanelemasta pakosta. Paljon enempää en olisi kenttätyötä voinut edes järjestää, sillä tälläkin tavoin vietin kaikki yliopiston lomat kevätlukukaudella Karjaalla. Koska tutkimukseni pääasiallinen anti ei tullut havainnoinnin kautta, en kokenut kenttätyöjaksojani riittämättömiksi, vaan mielestäni sain tarpeeksi tietoa tälläkin havainnointimäärällä. 


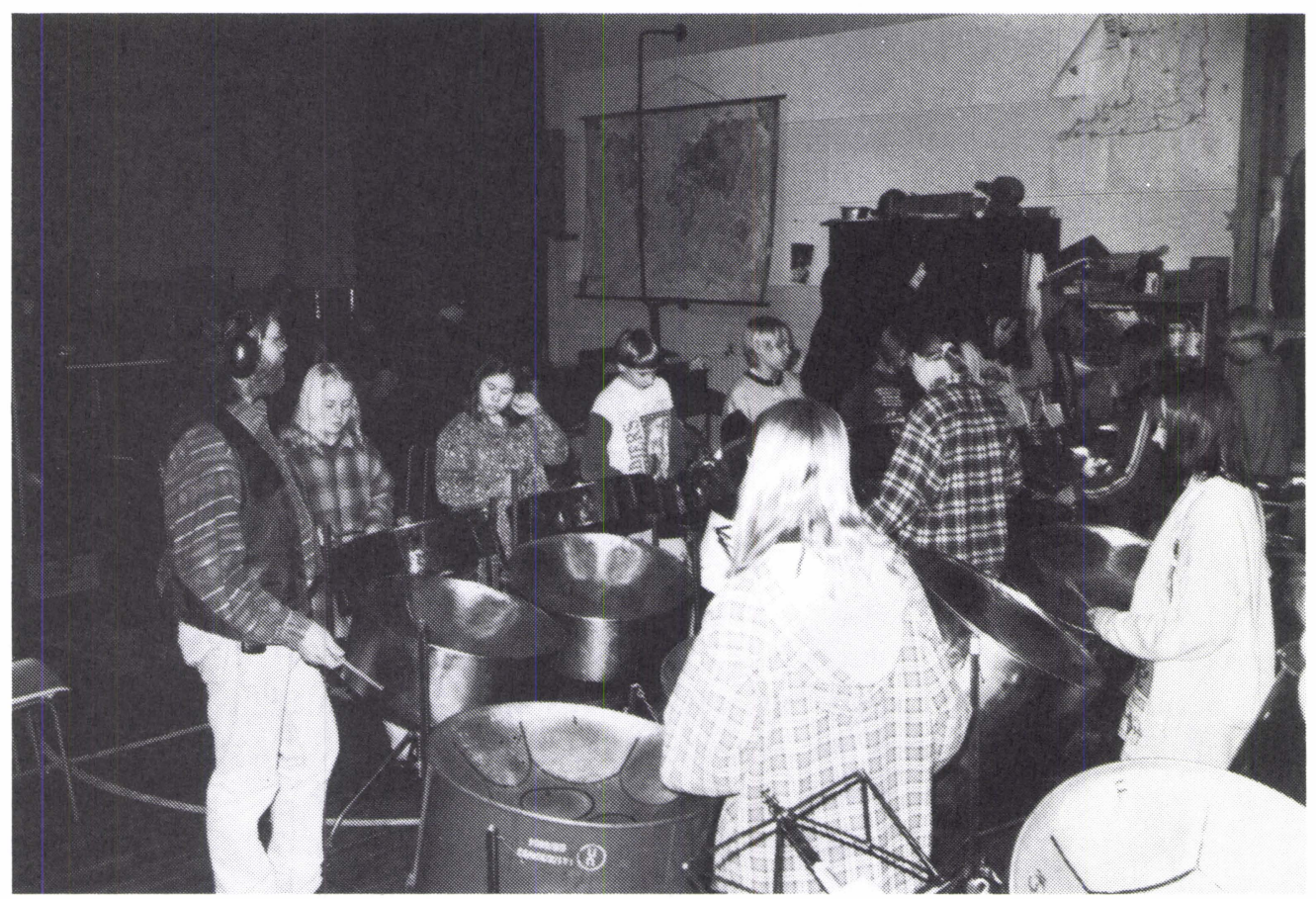

Kuva 2. Ari Viitasen musiikin tunneilla Karjaan suomalaisella yläasteella soitetaan steel panejä. Kuva Raija Kaljunen.

\subsubsection{Kysely}

Tarkoitukseni oli kyselyn avulla saada selville oppilaiden yleistä suhtautumista steel paneihin koulusoittimina, joten halusin mukaan suuremman joukon kuin yhden musiikinryhmän. Kaikki Karjaan suomalaisen yläasteen ja Karjaan lukion oppilaat olisi ollut liian suuri perusjoukko. Harkinnanvaraisesti valitsin tutkimukseen osallistujiksi ne musiikinryhmät, jotka soittavat säännöllisesti steel panejä eli kaikki yläasteen ryhmät. Lukiolaisista valitsin mukaan valinnaisen steelbandkurssin oppilaat, jotta saisin myös lukiolaisten mielipiteitä pannuista mukaan. Käytännössä vastaajiksi valitsin ne, joilla oli toisen kenttätyöjaksoni aikana musiikkia.

Kyselylomakkeen testaus tehtiin ensimmäisellä kenttätyöjaksollani tammikuussa 1996 Karjaan suomalaisella yläasteella siten, että 17 seitsemäsluokkalaista ja 8 kahdeksasluokkalaista täytti lomakkeen ja siihen liitetyn palautekyselyn. Palautekyselyssä tiedusteltiin Bellin $(1987,65)$ mallin mukaan muun muassa, kuinka kauan lomakkeen täyttämisessä meni, olivatko ohjeet selkeät ja oliko jokin tärkeä aihe jäänyt käsittelemättä. Lopullisen lomakkeen muotoilin koekyselyn täyttämisen yhteydessä saamani suullisen ja kirjallisen palautteen, Ari Viitasen 
kommenttien, seminaariryhmäläisteni palautteen ja omien ajatusteni pohjalta. Kysymystyyppien valinnassa ja käytännön ratkaisuissa auttoi Jyringin (1976) teos. Lomake sisälsi jonkin verran myös avoimia kysymyksiä, koska tällaista uutta aluetta tutkittaessa ei voi etukäteen olettaa vastausvaihtoehtoja. Kyselyn lopussa oli Walserin (1993, appendix 2) tutkimuksen lomakkeen mallin mukaan mahdollisuus antaa yhteystietonsa, jos oli halukas haastateltavaksi. Halukkuutensa ilmaisi 32 oppilasta $(28,1 \%$ vastanneista), joista valitsin 12 haastateltavaani.

Postitse suoritettavissa kyselytutkimuksissa on yleensä pidetty etuina taloudellisuutta, vastaanottajan parempaa tavoitettavuutta haastattelijaan verrattuna sekä kysymysten yhdenmukaisuutta kaikille vastaajille. Heikkouksina on pidetty muun muassa suurta vastaamattomuutta, joka ei ole satunnaista. Koottu aineisto on siten selektiivinen, mikä aiheuttaa harhaa pyrkimyksessä kuvata perusjoukkoa. Tutkijalla ei ole myöskään täyttä varmuutta siitä, kuka kyselyyn on vastannut. Ongelmana on ollut myös puutteellisesti täytetyt lomakkeet. Hirsjärven ja Hurmeen $(1988,16)$ mukaan lomakkeiden suurimpana heikkoutena on se, että tutkijan tekemät, omasta mielestään hyvin kattavat valmiit vastausvaihtoehdot, eivät läheskään aina tavoita vastaajan ajatusmaailmaa tai hänen maailmankuvansa olennaisia puolia. (Hirsjärvi-Hurme 1988, 16; Jyrinki 1976, 25 , 27.)

Tässä tutkimuksessa pyrin estämään kyselymenetelmän haittoja siten, että oppilaat täyttivät lomakkeen musiikintunnin aikana. Keräsin lomakkeet samantien takaisin, joten vastaamattomuus ja sen myötä selektiivisyys on minimoitu. Kysymysten yhdenmukaisuutta kaikille pyrittiin parantamaan siten, että olin läsnä oppilaiden täyttäessä lomakkeita, jolloin he saivat kysyä minulta tarvittaessa täsmennyksiä. Pyysin oppilaita vielä tarkistamaan ennen lomakkeiden palauttamista, että he olivat vastanneet joka kohtaan.

Varsinaisen kyselyn toteutin toisella kenttätyöjaksollani eli 26.2.-1.3. Kyselyyn vastasi siten oppilaita 13:sta eri musiikinryhmästä. Resurssini huomioonottaen eli se, että Keski-Suomen hiihtolomaviikko oli ainoa, jolloin pystyin opintojen takia lähtemään koko viikoksi Karjaalle, ja koska halusin olla itse paikalla ja kerätä lomakkeet samantien, oli tämä ratkaisu ainoa mahdollinen. Kyselyyn vastanneista oli $61(=53,5 \%)$ tyttöjä ja $53(=46,5 \%)$ poikia.

\subsubsection{Oppilaiden haastattelut}

Koska kyselylomake on eduistaan huolimatta aina jossain määrin mekaaninen ja todellisuuden monimuotoisuuden huomiotta jättävä menetelmä, halusin syventää tutkimustani haastattelemalla oppilaita sekä muita avainhenkilöitä. Haastattelumenetelmäksi valitsin teemahaastattelun. Nauhoitin kaikki haastattelut C-kaseteille ja purin ne tietokoneella tekstinkäsittelyohjelmaa (Word 2.0) käyttäen.

Teemahaastattelu on puolistrukturoitu menetelmä, jossa haastattelun aihepiirit ovat tiedossa. Kysymyksiä ei ole kuitenkaan tarkkaan muotoiltu ja järjestetty, 
kuten strukturoidussa haastattelussa. Teemahaastattelua käytettäessä tutkija on usein kiinnostunut tutkittavan ilmiön perusluonteesta ja -ominaisuuksista sekä hypoteesien löytämisestä, ei niinkään ennalta asetettujen hypoteesien todentamisesta. (Hirsjärvi - Hurme 1988, 36, 40-41.)

Tutkittavat ilmiöt ja niitä kuvaavat peruskäsitteet hahmottuvat, kun perehdytään teoriaan ja tutkimustietoon. Ilmiöiden pääluokkia kuvaavat nimitykset ovat samalla myös teoreettisia peruskäsitteitä. Haastattelurungoksi ei laadita yksityiskohtaista kysymysluetteloa vaan teema-alueluettelo. Se on haastattelijan muistilistana ja keskustelua ohjaavana kiintopisteenä. Teema-alueet "operationaalistetaan" haastattelutilanteessa kysymyksillä. Myös tutkittava toimii operationaalistajana. (Hirsjärvi - Hurme 1988, 41.)

Hirsjärvi ja Hurme suosittelevat $(1988,57)$, että esihaastatteluja tulisi suorittaa useassa vaiheessa. Esihaastattelujen avulla testataan haastattelurunkoa, aihepiirien järjestystä ja kysymysten muotoilua. Näin saadaan selville myös haastattelujen keskimääräinen pituus (Hirsjärvi - Hurme 1988, 57.)

Tämän tutkimuksen haastattelut tein Karjaalla kolmannella kenttätyöjaksolla 9.-12.4.1996, joka oli pääsiäisloman jälkeinen viikko. Haastateltavia valitsin joka luokka-asteelta siten, että 7.-luokkalaisia oli kolme, 8.-luokkalaisia kolme, 9.luokkalaisia kolme ja lukion steelband-kurssilaisia kolme, yhteensä 12 oppilasta. Haastateltavat valitsin lomakkeessa vapaaehtoisiksi ilmoittautuneista 32 oppilaasta, joiden kaikkien lomakkeet silmäilin läpi valintoja tehdessäni. Pyrin valitsemaan tyttöjä ja poikia musiikinryhmien sukupuolijakauman mukaisesti sekä ottaen huomioon 8.- ja 9.-luokkalaisten tapauksessa sen, että edustetuiksi tulevat sekä vaihtoehtoinen että valinnainen musiikki. Lopullisissa valinnoissa otin vielä huomioon, miten runsassanaisesti oppilas oli vastannut kyselyn avoimiin kysymyksiin. Tällä pyrin varmistamaan sen, että saisin mahdollisimman hyviä informantteja eli oppilaita, jotka osaavat ilmaista itseään ja siten olisivat hyödyksi tutkimuksessani. Halusin mukaan myös pannuihin negatiivisesti suhtautuneita oppilaita, jotta saisin tasapuolisen kuvan ilmiöstä.

Tässä tutkimuksessa en ajanpuutteen vuoksi voinut suorittaa esihaastatteluja. Teema-alueita hahmottelin sekä kyselyn että omien ajatusteni pohjalta. Haastattelin viittä poikaa ja seitsemää tyttöä Karjaan suomalaisen yläasteen tiloissa. Jokaisen haastattelun alussa kerroin oppilaalle, että he esiintyvät nimettöminä tutkimuksessa ja että haastattelussa annetut tiedot eivät mene ulkopuolisille. Nauhurin pidin valmiina jo pöydällä, enkä tehnyt sen käynnistämisestä suurta numeroa. Kukaan ei protestoinut haastattelun nauhoittamista. Haastatteluissa kesti noin 45-60 minuuttia per oppilas.

Syynä haastattelun epäonnistumiseen saattaa olla haastateltavan hankaluus, oma väsymys tai tilapäinen motivaation puute, tai haastatteluympäristön vaikeus. Usein kokematon haastattelija ei tunne tarpeeksi hyvin teemaluetteloa, ei kuuntele tarpeeksi vastauksia, vaan keskittyy kysymysten esittämiseen. Tämä on vakava virhe teemahaastattelussa, jossa seuraava kysymys riippuu tavallisesti edellisestä vastauksesta. (Hirsjärvi - Hurme 1988, 103-104.) 
Joskus haastattelu sujuu väkinäisesti tai epätarkoituksenmukaisen niukasti. Jos haastateltava vastaa kysymyksiin koko ajan "en mä tiedä", hän ei ehkä todellakaan tiedä tai on luonteeltaan arka tai varautunut. On myös mahdollista, että hänen elämäntilanteensa on niin vaikea, ettei hän voi keskittyä haastatteluun. Kokemuksen lisääntyessä haastattelija huomaa, että hiljaisuus voi synnyttää syvällisemmän vastauksen. Aloitteleva haastattelija helposti täyttää hiljaiset hetket lisäkysymyksillä tai omilla kommenteillaan. (Hirsjärvi - Hurme 1988, 92, 100.)

Koin oppilaiden haastattelemisen melko helpoksi. Toimittajataustani vaikutti varmasti siihen, että uusien ihmisten lähestyminen ei ole minulle vaikeaa ja haastattelu tilanteena on tuttu. Teemahaastattelu vaati silti erityistä huolellisuutta, ja etenkin ensimmäisissä haastatteluissa huomasin olevani liikaa vielä kiinni teemalistassa. 3-4 teemahaastattelua peräjälkeen on myös rankka urakka, ja välillä keskittymiskykyni oli koetuksella. Helpompaa olisi ollut tehdä esimerkiksi kolme haastattelua päivässä parin tunnin välein, mutta aikataulullisesti tämä ei ollut mahdollista. Koin silti pääseväni oppilaiden kanssa "samalle aaltopituudelle", ja vain parissa tapauksessa vastaukset olivat häiritsevän paljon "emmätiiä"tyylisiä. Taitoni kestää hiljaisuutta parani myös haastattelujen myötä. Pidin esillä kunkin oppilaan täyttämää kyselylomaketta, joka oli erittäin hyvä tuki haastattelussa. Jokaisen haastateltavan jälkeen kirjoitin myös lyhyet muistiinpanot, joissa arvioin haastateltavien avoimuutta ja merkitsin muistiin omia tuntemuksiani.

\subsubsection{Muut haastattelut}

Haastattelin tutkimustani varten Ari Viitasta pariin otteeseen kevätlukukaudella 1996 ja käytin aineistona myös epävirallisempia keskustelujamme, joita kirjasin kenttämuistiinpanoihini. Proseminaarityötäni varten tekemäni Arin haastattelut 4.1. ja 28.2.-95 ovat myös osa tutkimustani. Yksi osio aineistosta syntyi siten, että olin miettinyt Arille teema-alueita hänen musiikkikasvatusfilosofiastaan. Ari pohti näitä asioita kotonaan ja lähetti kasetille nauhoittamansa "vastauksensa" minulle. Niin Arin kuin muidenkin haastattelut toteutin teemahaastatteluina. Osassa haastatteluja teema-alueisiin sisältyi varsin yksityiskohtaisiakin etukäteen mietittyjä alueita, mutta itse haastattelutilanteessa käsittelyjärjestys ja sanamuoto riippuivat aina tilanteesta.

Muita haastateltaviani olivat Karjaan suomalaisella ala-asteella työskentelevä luokanopettaja Antti Jyrkkänen, Karjaan suomalaisen yläasteen rehtori Toivo Kukkonen, Karjaan lukion rehtori Eija Gustafsson, Kirkkonummen Kirkkoharjun koulun musiikin lehtori Satu Jämsä sekä sveitsiläinen pannunrakentaja Werner Egger. Kaikista haastatteluista tein haastattelumuistiinpanot. Haastattelut purin nauhalta teema-alueittain, en sanatarkasti joka kohtaa. 


\subsubsection{Muu kenttätyömateriaali}

Tutkimukseni muu materiaali koostuu kenttätyöjaksoilla ottamistani valokuvista ja noin kahden tunnin mittaisesta videonauhasta. Kuvia tai nauhaa en ole systemaattisesti analysoinut, vaan ne ovat olleet lähinnä muistinvirkistämistä varten. Valokuvia olen käyttänyt tutkimukseni havainnollistamiseksi. Kysyin Viitaselta luvat kuvaamiseen ja videointiin: häntä valokuvaus ja videointi eivät tuntuneet mitenkään häiritsevän. Oppilaatkaan eivät suuremmin tuntuneet kiusaantuvan salamavalosta tai videokamerasta.

Muu kenttätyömateriaali, jota olen käyttänyt tutkimuksessani, koostuu Karjaan suomalaisen yläasteen ja lukion vuosikertomuksista vuodesta 1988-89 vuoteen 1995-96, koulujen omista opetussuunnitelmista sekä Viitasen tekemistä musiikin opetussuunnitelmista. Perehdyin myös sanomalehti Länsi-Uusimaan Ari Viitasesta ja steel paneista kertoviin artikkeleihin vuosilta 1990-96.

\subsection{Metodikirjallisuus}

Steel panejä, niiden historiaa ja Trinidadia koskevaan kirjallisuuteen tutustuin jo proseminaarityötä tehdessäni talvella 1995-96. Tätä tutkimusta varten aloin kartoittaa kirjallisuutta syksyllä 1995. Steel paneistä ei juurikaan kirjallisuutta ole, mutta tapaustutkimuksesta, etnografiasta ja laadullisesta tutkimuksesta yleensäkin lähteitä on saatavilla runsaasti. Kirjoihin ja artikkeleihin olen perehtynyt koko tutkimusprosessin ajan, mikä osoittautui hyväksi ratkaisuksi. Koska kenttätyön aikana näkemykset tutkimuksesta muuttuvat, aiheet tarkentuvat ja tapahtuu ongelmien rajaamista, ei etukäteen päätetty viitekehys välttämättä olisi pitänyt paikkaansa.

\subsection{Aineiston analysointi}

Aineiston, sekä kirjallisuuden että kenttätyöaineiston, analysointi alkoi jo oikeastaan heti ensimmäistä Viitasen tuntia seuratessani. Kenttämuistiinpanoni sisältävät alustavia tulkintojani asioista ja teemojen kehittelyä. Prosessi on ollut käynnissä koko tutkimuksen etenemisen ajan, ja lopulliset ratkaisut kirkastuneet vasta kirjoitusvaiheessa.

Havainnoinnista koostuneet, puhtaaksikirjoitetut kenttämuistiinpanot käsittelin siten, että luin niitä useaan otteeseen läpi. Kun tietyt teemat nousivat esiin kautta aineiston, aloin tehdä merkintöjä marginaaleihin. Sen jälkeen koostin nämä teemoittaiset alueet eri tiedostoksi. Kyselylomakkeen avoimet kysymykset koodasin itse siten, että jaottelin oppilaiden vastaukset sisällönanalyysin periaattein eri luokkiin ja merkitsin luokan numeron kussakin kohdassa lomakkeisiin. Aineiston tallennus tietokoneelle tapahtui Jyväskylän yliopiston ATK-kes- 
kuksessa toukokuun lopussa 1996.

Haastatteluaineiston käsittelyssä sisällönanalyysi voi olla joko kvalitatiivista tai kvantitatiivista. Kummassakin tapauksessa sitä ohjaavat jo suunnitteluvaiheessa keskeisiksi havaitut käsitteet, alustavasti asetetut hypoteesit sekä teemahaastattelun aikana syntyneet hypoteesit. Tältä pohjalta valitaan muuttujat. Kvalitatiivisessa tarkastelussa muuttujan luokat voivat olla epätarkempia rajoiltaan. Tarkasteluyksikkö voi olla teemahaastattelussa esimerkiksi yksittäiset sanat tai teemat. (Hirsjärvi - Hurme 1988, 115.)

Tässä tutkimuksessa haastattelut purettiin teema-alueittain siten, että kaikkien vastaajien samaa aluetta käsittelevät vastaukset koottiin yhteen. Ensiksi kuitenkin purettiin jokainen haastattelu erikseen, ja ne myös säilytettiin alkuperäisessä muodossaan teema-alueittaisen koostamisen jälkeen.

\section{Steel panien mahdollisuudet musiikinopetuksessa}

Ari Viitasen, Satu jämsän ja Antti Jyrkkäsen ajatukset steel paneistä ja niiden hyvistä puolista musiikinopetuksessa ovat hyvin samansuuntaisia. Kaikki korostavat sitä, miten pannut luovat yhteishenkeä: oppilaat ovat innokkaasti työskennelleet yhdessä opetellessaan kappaleita. Viitasen oppilaista suurin osa on kokenut pannujensoiton parantaneen musiikinryhmänsä yhteishenkeä, ja yhteissoittoa pidettiin helppona. Havaitsin itsekin yhteishengen Viitasen tunneilla lähes poikkeuksetta erittäin hyväksi. Oppilaat tuntuivat suhtautuvan tosissaan kappaleiden harjoitteluun. Viitasen tunneilla oppilaat myös auttavat ja neuvovat paljon toisiaan, mikä on myös osoitus hyvästä työskentelyilmapiiristä. Erittäin tärkeäksi sekä oppilaat että opettajat kokivat yhteissoiton; sen, että steel panit mahdollistavat kaikkien osallistumisen soittamiseen. Jyrkkäsen ja Jämsän tapauksissa soitinten vähyys estää koko ryhmän osallistumisen, mutta molemmat ovat ratkaisseet asian vuorottelemalla soittajia. Tavoissa opettaa pannukappaleita oli havaittavissa samankaltaisuutta: pieniä katkelmia opeteltiin edelleen kohti kokonaisuutta. Viitanen ja Jämsä eivät paljon käytä nuotteja, Jyrkkänen jakaa ne vain 5.-6. luokkalaisille.

Kyselystä ja oppilaiden haastattelusta kävi ilmi, että pannujensoitto on monessa suhteessa tuonut positiivisia elämyksiä suurimmalle osalle oppilaista. $\mathrm{He}$ ovat kokeneet oppineensa kuuntelemisen taitoja, soittamaan steel panejä, ja heidän kiinnostuksensa entuudestaan vieraampaa musiikkikulttuuria kohtaan on kasvanut. Pannujensoitto voidaankin nähdä hyvänä esimerkkinä ruohonjuuritason kansainvälisyyskasvatuksesta: trinidadilainen soitin ja musiikkikulttuuri ovat muuttuneet luontevaksi osaksi suomalaista kulttuuria. Pannujensoitto toteuttaa mitä oivallisemmin musiikin opetussuunnitelman perusteissa mainittuja tavoitteita myönteisistä elämyksistä, sosiaalisesta kasvatuksesta ja monipuolisesti eri musiikkikulttuureihin tutustumisesta (POPS 1994, 97; LOPS 1994, 101).

Kaikki kolme opettajaa ovat ihastuneet pannujen helppouteen koulusoittime- 
na: oppilaat aloittavat samalta tasolta ja jo yksinkertaisetkin kappaleet kuulostavat hyviltä pannuilla soitettuna. Myös oppilaat olivat samoilla linjoilla: soittaminen koettiin hauskaksi ja helpoksi, koska soittimiin on merkitty kirjaimet näkyviin, ja soittotekniikka on tuntunut helpolta. Oppilaat pitivät steel paniä mukavana, mielenkiintoisena ja hyvin kouluun soveltuvana soittimena.

Pannujensoitto vie opettajan helposti mukanaan, jolloin ehkäpä joitakin muita aiheita jää käsittelemättä tunneilla. Osa oppilaista, tosin selvä vähemmistö, kritisoi Viitasen opetuksessa pannujensoiton korostuneen ja muiden soitinten tai laulamisen jääneen liian vähälle. Satu Jämsän lukuvuoden 1996-97 ratkaisu on keskittää 7. luokkien pannujensoitto yhteen jaksoon, mikä on yksi tapa ratkaista asia. Koska tunteja on vähän, musiikinopettaja joutuu aina tekemään kompromisseja niin pannujen kuin muidenkin soitinten harjoittamisessa sekä käsiteltävien asioiden valinnassa. Musiikinopetuksen monipuolisuus on hyvä tavoite, mutta kaikkiin maailman musiikkikulttuureihin tutustuminen on mahdotonta. Uskonkin, että syvällisempi perehtyminen esimerkiksi karibialaiseen musiikkikulttuuriin pannujensoiton kautta antaa enemmän myös oppilaille verrattuna pinnallisiin pikatutustumisiin moniin eri musiikkeihin. Ihanneratkaisu tietysti olisi saada musiikille lisää tunteja.

Ari Viitanen itse on hyvin pitkälle miettinyt pannujensoiton filosofista puolta: kuinka sen kautta opitaan esimerkiksi toimimaan yhdessä, muuttamaan asioita parempaan suuntaan, kuuntelemaan, odottamaan ja näkemään yksilöiden erilaisuus ja arvostamaan toista ihmistä. Hänen tärkein tavoitteensa eli se, että ihminen kokisi musiikin kautta onnistumisen iloa ja ryhmään kuulumista, näyttäisi tämän tutkimuksen perusteella toteutuneen.

Steel pan on uusi ja erikoinen soitin, mikä osaltaan viehättää opettajia ja oppilaita Karjaalla ja Kirkkonummella. Sen ottaminen musiikinopetukseen vaatii paljon omaa innostusta ja ylimääräistä työtä, kuten esimerkiksi Satu Jämsä on saanut kokea. Lähiaikoina pannut tuskin leviävät meillä yhtä tavallisiksi koulusoittimiksi kuin esimerkiksi Yhdysvalloissa. Osaltaan yleistymistä hidastanee soitinten melko kallis hinta. Pannujen hankkiminen ja virittäminen ovat tällä hetkellä paljolti kiinni Ari Viitasesta. Steel panien huonoksi puoleksi on todettava se, että ne vaativat ison säilytystilan. Tutkimuskouluissa tämä ongelma on pystytty ratkaisemaan, ja koulut ovat muutenkin suhtautuneet varsin positiivisesti toimintaan. Viitanen, Jämsä ja Jyrkkänen ovat kokeneet saaneensa vaivannäöstään palkintona oppilaiden innostuksen ja oppimisen.

Koulun musiikkikasvatuksen kannalta steel paneillä on nähdäkseni monia etuja ja mahdollisuuksia suomalaisessa musiikinopetuksessa. Tämän tutkimuksen perusteella pannujensoitossa korostuu hyvin vahvasti kasvatuksellinen puoli: yhdessä tekeminen ja myönteiset elämykset. Tämä sama saavutetaan tietysti muussa orkesterisoitossa, mutta pannujen etuna on soittamisen helppous: motoriikka on yksinkertaista, nuotinlukua ei tarvitse osata ja soittamisessa päästään nopeasti tuloksiin. Koska monissa kouluissa musiikkia on esimerkiksi 7. luokalla vain yksi kaikille pakollinen kurssi, pystyttäisiin steel paniensoitolla lyhyessäkin 
ajassa luomaan positiivinen suhde musiikkiin oman musisoinnin kautta. Viitasen, Jämsä ja Jyrkkäsen tunneilla soitetaan paljon ulkoa, mikä osaltaan lisää oppilaiden henkilökohtaista suhdetta musiikkiin: on keskityttävä kuuntelemaan oma osuus ja opeteltava se - mahdollisesti tehtävä siitä vielä omat soittomuistiinpanot. Pannujensoitto on ilmeisen onnistunut yhdistelmä positiivisia elämyksiä ja toiminnallisuutta, ja tutkimuksen perusteella suosittelisin jokaiselle musiikinopettajalle tutustumista pannuihin.

\section{Lähteet}

Bell, Judith 1987. Doing your research project. A Guide for First-Time Researchers in Education and Social Science. Milton Keynes -

Philadelphia: Open University Press.

Bresler, Liora - Stake, Robert E. 1992. Qualitative Research Methodology in

Music Education. Teoksessa Colwell, R. (toim.), Handbook of Research on Music Teaching and Learning. A Project of the Music Educators

National Conference. New York: Schirmer Books.

Fetterman, David M. 1989. Ethnography. Step by Step. Applied Social

Research Methods Series. Volume 17. Newbury Park: Sage Publications.

Hirsjärvi, Sirkka - Hurme, Helena 1988. Teemahaastattelu. 4.painos. Helsinki:

Yliopistopaino.

Jyrinki, Erkki 1976. Kysely ja haastattelu tutkimuksessa. Toinen, uudistettu painos. Helsinki: Oy Gaudeamus Ab.

Kronman, Ulf 1992. Steel Pan Tuning. A Handbook for Steel Pan Making and

Tuning. Musikmuseets skriftserie 20. Stockholm: Musikmuseet.

LOPS = Lukion opetussuunnitelman perusteet . 1994. Helsinki: Opetushallitus.

Merriam, Alan P. 1978. The Anthropology of Music. Seventh printing

Northwestern. University Press.

Merriam, Sharan B. 1988. Case Study Research in Education. A Qualitative

Approach. San Francisco: Jossey-Bass Publishers.

POPS = Peruskoulun opetussuunnitelman perusteet . 1994. Helsinki:

Opetushallitus.

Seeger, Anthony 1992. Ethnography of Music. Teoksessa Myers, H. (toim.),

Ethnomusicology. An Introduction. The New Grove Handbooks in Music.

London: The Macmillan Press.

Slobin, Mark - Titon, Jeff 1992. The Music-Culture as a World of Music.

Teoksessa Titon, J. (toim.), Worlds of Music. An Introduction to the

Music of the World's Peoples. Second Edition. New York: Schirmer Books.

Syrjälä, Leena - Numminen, Merja 1988. Tapaustutkimus kasvatustieteessä.

Oulun yliopiston kasvatustieteiden tiedekunnan tutkimuksia 51/1988.

Syrjäläinen, Eija 1990. Oppilaiden ja opettajan roolikäyttäytyminen 
luokkahuoneyhteisössä. Etnografinen tapaustutkimus peruskoulun ja steinerkolun ala-asteen 4. vuosiluokalta. Helsingin yliopiston opettajankoulutuslaitos. Tutkimuksia 78.

Walser, Robert 1993. Running with the Devil. Power, Gender and Madness in Heavy Metal Music. Hanover: University Press of New England. 